\author{
M. Radomska ${ }^{1}$, Yu. Kartash ${ }^{2}$ \\ ${ }^{1}$ National Aviation University, Kyiv, Ukraine \\ ${ }^{2}$ LLC “Logistics”, Kyiv, Ukraine
}

\title{
THE COMPARATIVE ANALYSIS OF THE ENVIRONMENTAL AND ECONOMIC EFFICIENCY OF THE KYIV CITY PUBLIC TRANSPORT MODERNIZATION
}

\begin{abstract}
The subject matter of the study is the comparison of alternatives for the rennovation of public transport in Kyiv. The aim of the article is to define the most economically and environmentally efficient direction of public transport modernization under the conditions of Kyiv city. The following tasks are solved in the article: the problems of public transport management and development in major cities are analyzed, the possible approaches to public transport modernization under various conditions are considered, the methods for comparative analysis chosen and alternatives are formulated and described, the analysis of proposed alternatives is conducted and the best option is characterized in terms of its potential to reduce impacts on the urban environment, the economic parameters of the chosen alternative are compared with the other options. The following methods are applied - system analysis, matrix method, SWOT-analysis, PESTLEanalysis. The following results are obtained: the analysis of the impacts of transport system on the urban environment has demonstrated the urgent need for renovation of the vehicles and possibly their substitution with those based on new technological principles and power sources. The consideration approaches used by various countries has proved the absence of single strategy, as it must account specific traits of economic and urban planning situation in cities. The Ukrainian researches are also seen to have different opinions about the most efficient development of public transport. The characteristics of the Kyiv public transport and its problems have been given. Based on the aggregated information the list of potential alternatives to the existing public vehicles has been developed. The suggested alternatives have been studied according to a range of parameters with the help of matrix method. The most efficient option has been further investigated by means of the SWOT and PESTLE analysis to highlight its advantages and disadvantages. Conclusions. Each alternative has the right to be implemented and used for public transport in Kiev, its choice depends only on the available costs and the necessary time periods. The conducted research shows that under current conditions electric buses as a substitution option need moderate investments and will soon provide environmental and economic benefits.
\end{abstract}

Keywords : public transport; environment pollution; natural resources conservation; alternatives assessment.

\section{Introduction}

With more of the world's population living in urban areas, cities today face urgent and complex development challenges, as the largest agglomerations are now home to more than 10 million people. In order to manage the growing complexity of urban structure and provide the needs of all city inhabitants, managers and authorities have to balance economic priorities with degrading quality of environment, which interfere with the sustainable development targets.

Urban transportation systems significantly affect urban environment condition and standards of life and, through consequent air pollution and greenhouse gases, emissions impact the wider regional and global environments. These impacts can be mitigated by optimization of transport network to minimize travel times and congestion, reduce GHG emissions and local air pollutants. Another efficient approach to sustainability and environmental safety of urban transport is substitution of vehicles with modern and more environmentally friendly. This can have measurable positive impacts and externalities, but it is applicable only to public transport, which needs careful planning and substantiation to be affordable and technically feasible.

\section{Problem formulation}

The issues of public transport development are widely discussed by scholars and practitioners, politicians and non-governmental organizations. An important element of the process is assessment of environmental impacts transport and traffic related health effects. Thus, proves of the interaction between urban transport emissions and respiratory, circulatory and other health disorders among various groups of population can be found in the studies by Laumbach R.J. et al, Zhang K., Batterman S., Furie G.L. and Desai M.M., Evans G.W. These works rise the question of extremely needed modernization of transport, but give little ideas about the way to perform this task.

In Ukraine the works by Gutarevich Yu.F., Pavlychenko A.V., Siletsky A.E., Klebanova N.S., Kireeva I.S. et al also show a strong connection between the functioning of transport and environment degradation and health threats, as well as give general recommendations to the possible directions of work on the way to sustainable transport. However, the real technological options for the improvement of the situation are given in the works by Chernyshov O. and Dzymak M.A. [1, 2]. Legenky G.M., Mateichyk V.P, Zubyk S.V. develop some management and decision making approaches to the optimization of urban transport flow without its differentiation [3-5].

Still most of the challenge of public transport optimization remains an opened problem and provided with more set questions, than given answers. Developed countries and those with transitional economies are trying various options, including bus rapid transit, personal rapid transit systems, "mexicable", Olli selfdriving mini bus, etc. [6]. Some scientists, believe, that efforts should be invested in the development of rail transport [7] or solely electric transport [8]. Others 
consider the substitution of vehicles engines with more powerful and efficient as a major way to public transport modernization, providing the substantiation of the best choices in terms of meeting emission standards, noise control and fuel efficiency [9].

Thus, the aim of the given research is the comparative assessment of possible alternatives for technical modernization of Kyiv public transport, considering a wide variety of potential projects.

\section{Methods and materials}

One of the most convenient methods to analyze a wide set of data about alternatives of project activity is the method of matrices.

A matrix is a table that is used to identify the interaction between project activities or different projects themselves, which are displayed along one axis, and environmental, economic and social characteristics, which are displayed along the other axis. Using the table, factor-activity interactions can be marked at the intersections either by ticks to highlight the presence of interdependence, symbols to identify impact type (such as direct, indirect, cumulative) or numbers to show impact severity or other features related to the nature of the project.

For the purpose of the given study the following parameters of the projects are to be considered:

F1 = degree of achieving overall objective;

$\mathrm{F} 2$ = economic efficiency of the project;

F3 = social concerns in the project area;

$\mathrm{F} 4=$ negative impacts on the environment;

F5 = positive impacts on the environment;

F6 = human health threats for local population;

F7 = technical feasibility.

Each parameter is scored for each project in points from 0 to 3 , where 0 represents the least favorable value of the parameter. The sum of points stands for the total score of the project with the maximal being the indicator of the best choice.

Another suitable method to characterize any kind of project in terms of its benefits and drawbacks is SWOT-analysis. It is used in strategic planning, and involves formulation of project characteristics in four categories: Strengths, Weaknesses, Opportunities, and Threats. The purpose of this analysis is to identify its internal forces to maximize the use of external capabilities and identify the weaknesses of the object, which can complicate the problems associated with external threats.

The PEST analysis (political, economic, sociocultural and technological) describes a framework of macro-environmental factors used in the environmental scanning component of strategic management. It is part of an external analysis when conducting a strategic analysis, and gives an overview of the different macroenvironmental factors to be taken into consideration. It is a strategic tool for understanding development trends, potential and direction for operations.

\section{Results and discussions}

1. State and characteristics of the transport system in the Kyiv city. Kyiv has a developed transport infrastructure, which consists of highways, railways, waterways and bridges; road transport, subway, tram, trolley bus routes are developed here. The dominant role in public transport belongs to busses of various capacity (58\% of transportation), trolleybus $(26 \%)$ and trams $(11 \%)$. The major problems of public transport in the city are technical condition and planning. Thus, the work of public transport in the city is not balanced: city faces long traffic jams; there is a strip for public transport, but it is occupied by cars; public transport is unattractive, because it is late as a result. Careful planning and efficient system of fines and penalties can solve these problems. While the bad technical condition and big age of vehicles is by far more serious issue, as it is the direct reason for environment pollution and waste of energy carriers.

It should be also noted that the bulk of medium and high-capacity buses are equipped with diesel engines. According to the stated technical data, the bus fleet meets obsolete environmental norms of Euro-2 and Euro-3, while Euro-5 standards are in force in Ukraine since 2016.

So, we have chosen a range of alternatives to solve the problem of public transport modernization:

A1 - Replacement of the vehicle Bogdan A-092 with new models (Bogdan A092.02 in comparing with Bogdan A302-12);

A2 - Replacement of buses with internal combustion engine by electric busses;

A3 - Replacement of buses with internal combustion engine by trolley buses;

A4 - Replacement of buses with ICE and diesel fuel with bunkers on liquefied / compressed gas;

A5 - Use of buses, whose emissions correspond to the environmental standards Euro-5 to Euro-6;

A6 - Implementation of high-speed bus transport system (BRT) for short route.

Each of these alternatives has been fully analyzed with application of the above-mentioned methods. It was important to account the level to which an alternative meets the targets of reducing natural resources consumption and environment pollution. The last issue is measured with the volume of emissions, noise pollution and required construction works. When it is applicable the calculation of emissions was attributed to the bus route number 211 .

The technical and technological requirements, necessary transformation of the existing infrastructure (construction of rails, power lines, etc.), time and money investments have been also given a high priority in the analysis of the alternatives.

2. Comparative analysis of alternatives. The results of evaluation using matrix method are given in Table 1. The last column of the table contains total score for each alternative and the final choice of the best alternative is done based on it.

Having described each alternative, its advantages and disadvantages, we see that A2 - replacement of buses' internal combustion engine with the electric engine - is the most perspective. This alternative will be efficient after the first months of its implementation and does not overuse costs, which is very important. 
Table 1 - Results of comparative evaluation

\begin{tabular}{|c|c|c|c|c|c|c|c|c|}
\hline \multirow{2}{*}{$\begin{array}{c}\text { Alter- } \\
\text { natives }\end{array}$} & \multicolumn{7}{|c|}{ Factors } & \multirow{2}{*}{ Total } \\
score \\
\cline { 2 - 9 } & F1 & F2 & F3 & F4 & F5 & F6 & F7 & \\
\hline A1 & 2 & 2 & 3 & 2 & 2 & 1 & 2 & 14 \\
\hline A2 & 3 & 3 & 2 & 3 & 3 & 1 & 2 & 17 \\
\hline A3 & 2 & 2 & 3 & 3 & 2 & 2 & 1 & 15 \\
\hline A4 & 0 & 1 & 2 & 0 & 1 & 1 & 2 & 7 \\
\hline A5 & 2 & 2 & 3 & 2 & 3 & 2 & 1 & 15 \\
\hline A6 & 2 & 2 & 3 & 2 & 2 & 1 & 1 & 14 \\
\hline
\end{tabular}

The second leading alternative №5 is the introduction of vehicles, meeting the highest Euro-6 standards.

It will be very positive and efficient for the environment, but it will draw uncertainties about how to deal with vehicles that still use Euro 2 and Euro 3 standards.
Also the second place is shared by the alternative №3 - the use of trolley buses instead of city buses Bogdan-A092. But this alternative requires a lot of investment in the grid to create all the routes. Also the travel time of the route may increase, and the trolleybus itself will not be maneuverable on the road.

Alternative number 1 and number 6 have their own advantages and disadvantages, which were stronger than the benefits. Significant investment will not allow these alternatives to become the most effective.

The worst result was of alternative №4 replacement of buses with ICE and diesel fuel by liquefied/compressed gas. This alternative will not bring much positive changes for the environment and will be of little economic efficiency.

The general summarized Table 2 shows main perspectives of implementing these projects. In order to present the relative efficiency of the considered alternatives their economic and environmental parameters have been compared with a so called "zero alternative" - the existing most common type of buses, used in Kyiv, in percents (Fig. 1).

Table 2 - Environmental and economic parameters for proposed alternatives

\begin{tabular}{|l|c|l|c|c|c|}
\hline Alternative & $\begin{array}{c}\text { Total } \\
\text { emissions, } \\
\text { t/year * }\end{array}$ & $\begin{array}{c}\text { Environmental } \\
\text { problems } \\
\text { solved }\end{array}$ & $\begin{array}{c}\text { Cost of } \\
\text { implementation, } \\
\text { UAH* }\end{array}$ & $\begin{array}{c}\text { Payback } \\
\text { period, months }\end{array}$ & $\begin{array}{c}\text { Technical } \\
\text { complexity }\end{array}$ \\
\hline A1 & 0,595 & emissions reduction & 605000 & 3,4 & Medium \\
\hline A2 & 0 & $\begin{array}{l}\text { noise reduction; } \\
\text { pollution reduction }\end{array}$ & 24490 & 29 & High \\
\hline A3 & 0 & $\begin{array}{l}\text { noise reduction; } \\
\text { pollution reduction }\end{array}$ & $6 \mathrm{mln}$ & Medium \\
\hline A4 & 0,202 & emissions reduction & 50000 & $>1$ & High \\
\hline A5 & 0,571 & emissions reduction & 10000 & 112 & High \\
\hline A6 & 0 & $\begin{array}{l}\text { noise reduction; } \\
\text { pollution reduction }\end{array}$ & $\sim 20 \mathrm{mln}$ & & $>1$ \\
\hline
\end{tabular}

\section{*Based on 1 vehicle}

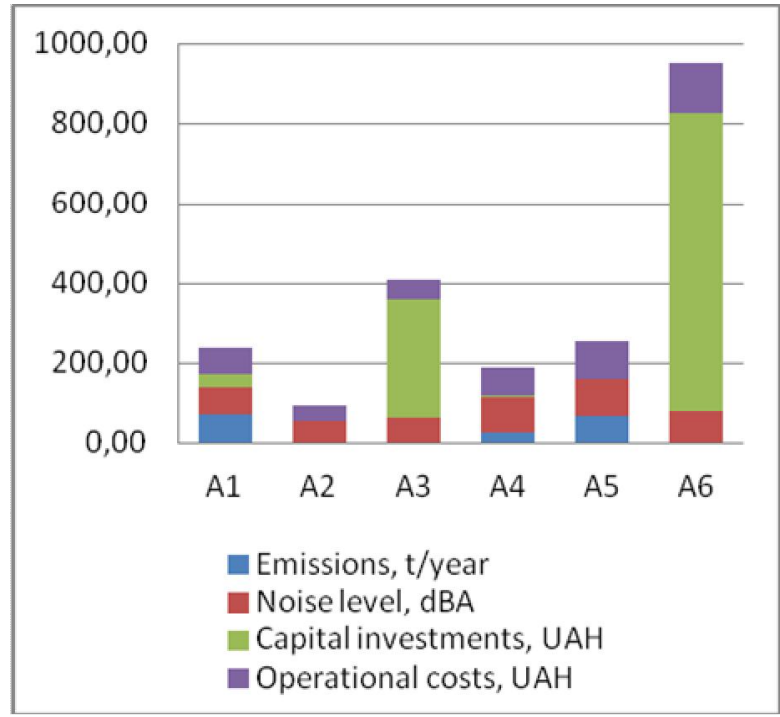

Fig. 1. Percentage ratio of the proposed options characteristics and the vehicles used
3. Environmental and economic assessment of the proposed alternative of modernization for bus routes

The assessment of the environmental and economic efficiency of projects is an integral part of the assessment of the effectiveness of the project as a whole, clearly showing the purpose of this project and the time frame for its achievement.

To clearly represent all advantages and disadvantages of Alternative №2 the SWOT-analysis and PESTLE-analysis have been conducted. Such these methods help show any risks or positives for Alternative implementation.

So, the strengths of the project are:

- decrease of emissions;

- noise reduction on the roads;

- increase revenue by reducing fuel costs;

- reduced fare;

- expansion of the enterprise, through the acquisition of new machines. 
Weaknesses of the project, which must be addressed at the planning stage :

- lack of full charging stations for vehicles;

- insufficient number of nationally produced batteries;

- lack of national incentive policies for alternative modes of transport;

- high requirements for the operation of electrical equipment, sensitivity to undercharging;

- insufficient maintenance and personnel skills in the use of the electric motor

- temperature sensitivity.

External factors of the market form the following threats to the alternative:

- increasing market competitiveness;

- electromagnetic radiation for staff;

- growing prices of electricity;

- lack of policies and legislation for recycling, recovery and re-use of the electric motor, which will lead to a new type of pollutants.

However, under given realities of Ukraine implementation of such project creates a range of valuable external opportunities for other branches of economy: services

- increased demand for passenger transport

- growing demand for transport models of national production;

- emergence of new investment projects for electric vehicles.

Thus, based on the analysis of this alternative, we see that the weak sides and shortcomings of this project have a place to be. But at the same time, the qualitative positive parameters remain more impressive and promising

The knowledge about obstacles and weak sides enables their mitigation or even transformation into positive.

PEST analysis is a simple yet important tool that will help understand the overall picture of the political, economic, socio-cultural and technological environment for implementing A2.
In our case the PESTLE-analysis has shown that in order to achieve all the goals of the project, it is necessary not only to have enough financial provision, but also to have the support at the national and regional levels, social support from media and improved education to information of population.

\section{Conclusions}

1. The analysis of available publications shows that urban transport is a source of major environmental problems and human health threat. Yet, it remains an important element of high living standards.

2. Despite the wide variety of research in the field of transport impacts mitigation, applied technical solutions for transport modernization are not available.

3. Six potential alternatives of Kyiv public transport modernization have been identified and analyzed. Environmental and economic efficiency of the project is an indicator characterizing the ratio of the overall economic benefits and losses from the project, including external environmental effects, and the associated social and economic consequences affecting the interests of the population and future generations as a result of the project.

4. Replacement of buses with internal combustion engine by electric buses has turned out to be the most effective due to low economic costs, short implementation period and operational feasibility.

5. The SWOT and PESTLE analysis for the chosen alternative showed that the main obstacles for its implementation will be the lack of programs in the National Policy, insufficient quality production of electric motors by national manufacturers, lack of market competition.

In total, each alternative has the right to be implemented and used for public transport in Kiev; its choice depends only on the available costs and the necessary time periods.

The lack of additional investment funds limits the introduction of promising alternative projects for the modernization of bus routes.

\section{REFERENCES}

1. Chernyshov, O. (2016), Influence of transport on the ecology of the city. Analysis and Strategies for Ukraine, City Reforms, Kharkiv, $24 \mathrm{p}$.

2. Dzumak, M.A. and Kravchuk, G.I. (2011), "Eco-technology methods of noise reduction of anthropogenic origin in Vinnitsa", Collection of scientific works of Vinnitsa National Agrarian University. Series Technical Sciences, No. 8, pp. $100-108$.

3. Lehenky, G.M., Redziuk, A.M., Belous, A.M., Gutarevich, Yu.F. and Mateichik, V.P. (2000), "Basic directions of development of an environmentally acceptable transport system in Ukraine and ways of their implementation", Motorway of Ukraine, No. 3, pp. 24-26.

4. Schöbel, A. (2006), Optimization in Public Transportation Springer, Boston, 274 p., DOI: https://doi.org/10.1007/978-0-387-36643-2

5. Zubik, S.V. (2013), "Transport noise of the city and ways of its decrease", Scientific Bulletin of the National Forestry University of Ukraine, No. 23, pp. 126-131.

6. Hidalgo, D. and Carrig, A. (2010), Modernizing public transportation. Lessons learned from major bus improvements in Latin America and Asia, World Resources Institute, Washington, 44 p.

7. Jean-Paul, Rodrigue (2017), The Geography of Transport Systems, Routledge, New York, 440 p.

8. Gnedin, K.V. (2007), "Problems and Prospects of Urban Electric Transport Development", Bulletin of the Chernihiv State Technical University, No. 1 (15), pp. 184-187.

9. Mateichik V., Khrutba V., Zyuzyun V. and Samoilenko, I. (2012), "Analysis of environmental and social risks in transport systems development projects", Systemy i srodki transportu samochodowego / Seria TRANSPORT, Politechnika Rzeszowska im. Ignacego Lukasiewicza, Rzeszow, No. 3, pp. 105-112. 


\section{Відомості ПРО АвтоРів / AвоUT тHE AUTHORS}

Радомська Маргарита Мирославівна - кандидат технічних наук, доцент, доцент кафедри екології, Національний авіаційний університет, Київ, Україна;

Margaryta Radomska - Candidate of Technical Sciences Associate Professor, Associate Professor of the Department of Ecology, National Aviation University, Kyiv, Ukraine; e-mail: m.m.radomskaya@gmail.com; ORCID ID: http://orcid.org/0000-0002-8096-0313

Карташ Юлія Геннадіївна - начальник відділу, товариство з обмеженою відповідальністю «Логістика», Київ, Україна Kartash Yulia - Head of Department, LLC "Logistics", Kyiv, Ukraine e-mail: kartashy@ukr.net; ORCID ID: http://orcid.org/0000-0002-6507-0398

\section{Порівняльний аналіз еколого-економічної ефективності модернізації громадського транспорту міста Києва \\ М. М. Радомська, Ю. Г. Карташ}

Анотація. Предметом дослідження $є$ порівняння альтернатив оновлення громадського транспорту в Києві. Метою статті $\epsilon$ визначення найбільш економічно та екологічно ефективного напряму модернізації громадського транспорту в умовах міста Києва. У статті вирішуються наступні завдання: аналіз проблем управління та розвитку громадського транспорту у великих містах, розгляд можливих підходів до модернізації громадського транспорту за різних умов, вибір методів порівняльного аналізу та формулювання альтернатив, аналіз запропонованих альтернатив, характеристика потенціального зменшення впливу на міське середовище за рахунок обраного варіанту, порівняння економічних параметрів обраної альтернативи з іншими варіантами. Застосовуються такі методи - системний аналіз, матричний метод, SWOT-аналіз, PESTLE-аналіз. Отримані наступні результати: аналіз впливу транспортної системи на міське середовище продемонстрував нагальну необхідність у оновленні транспортних засобів i, можливо, їх заміни тими, що базуються на нових технологічних принципах і джерелах енергії. Розглянуті підходи різних країн до вирішення даного завдання довели відсутність єдиної стратегії, оскільки вона повинна враховувати особливості економічної та містобудівної ситуації. Українські дослідники також мають різні думки щодо найбільш ефективного шляху розвитку громадського транспорту. Наведено характеристики громадського транспорту м. Києва та його проблем. На основі агрегованої інформації було розроблено перелік потенційних альтернатив до існуючої структури громадського транспорту. Запропоновані альтернативи були досліджені за діапазоном параметрів за допомогою матричного методу. Найбільш ефективний варіант був додатково вивчений за допомогою SWOT та PESTLE аналізу, щоб висвітлити його переваги та недоліки. Висновки. Кожна альтернатива має право реалізовуватися i використовуватись для громадського транспорту в Києві, іiі вибір залежить тільки від наявних коштів і необхідного часу. Проведені дослідження показують, що в сучасних умовах електричні автобуси як варіант заміщення потребують помірних інвестицій і швидко принесуть екологічні та економічні вигоди.

Ключові слова: громадський транспорт; забруднення навколишнього середовища; збереження природних ресурсів; оцінка альтернатив.

\section{Сравнительный анализ эколого-экономической эффективности модернизации общественного транспорта города Киева \\ М. М. Радомская, Ю. Г. Карташ}

Ан нот а ци я. Предметом исследования является сравнение альтернатив обновления общественного транспорта в Киеве. Целью статьи является определение наиболее экономически и экологически эффективного направления модернизации общественного транспорта в условиях города Киева. В статье решаются следующие задачи: анализ проблем управления и развития общественного транспорта в крупных городах, рассмотрение возможных подходов к модернизации общественного транспорта в различных условиях, выбор методов сравнительного анализа и формулировка альтернатив, анализ предложенных альтернатив, характеристика потенциального уменьшения воздействия на городскую среду за счет избранного варианта, сравнение экономических параметров выбранной альтернативы с другими вариантами. Применяются такие методы - системный анализ, матричный метод, SWOT-анализ, PESTLE-анализ. Получены следующие результаты: анализ влияния транспортной системы на городскую среду продемонстрировал настоятельную необходимость в обновлении транспортных средств и, возможно, их замены такими, которые основаны на новых технологических принципах и источниках энергии. Рассмотрение подходов различных стран к решению данной задачи доказало отсутствие единой стратегии, поскольку она должна учитывать особенности экономической и градостроительной ситуации. Украинские исследователи также имеют разные мнения касательно наиболее эффективного пути развития общественного транспорта. Приведены характеристики и проблемы общественного транспорта г. Киева. На основе собранной информации был разработан перечень потенциальных альтернатив существующей структуры общественного транспорта. Предложенные альтернативы были исследованы по диапазону параметров с помощью матричного метода. Наиболее эффективный вариант был дополнительно изучен с помощью SWOT и PESTLE анализа, чтобы выделить его преимущества и недостатки. Выводы. Каждая альтернатива имеет право реализовываться и использоваться для общественного транспорта в Киеве, ее выбор зависит только от имеющихся средств и необходимого времени. Проведенные исследования показывают, что в современных условиях электрические автобусы как вариант замещения требуют умеренных инвестиций и быстро принесут экологические и экономические выгоды.

Ключевые слова: общественный транспорт; загрязнение окружающей среды; сбережение природных ресурсов; оценка альтернатив. 